\title{
Lichenometry and Schmidt hammer tests in the Kaunertal glacier foreland (Ötztal Alps) during the AMADEE-15 Mars Mission Simulation
}

Abstract

The aim of this article is to show the results of the lichenometrical and Schmidt hammer measurements performed in 2015 during the AMADEE-15 Mars Mission Simulation in the Ötztal Alps in order to test the capabilities of analogue astronauts and collect information on the geomorphic history of the study area since the Little Ice Age (LIA). The results obtained differ significantly from our expectations, which we attribute to differences in the field experience of participants and the astronauts' technical limitations in terms of mobility. However, the experiments proved that these methods are within the range of the astronauts' capabilities. Environmental factors, such as i) varied petrography, ii) varied number of thalli in test polygons, and iii) differences in topoclimatic conditions between the LIA moraine and the glacier front, further inhibited simple interpretation. The LIA maximum of the Kaunertal glacier occurred in AD 1850, and relative stabilization of the frontal part of the rock glacier occurred in $A D 1711$.

Keywords

AMADEE-15 Rock Glacier Mars Simulation - Kaunertal glacier • Alps • lichenometry $\cdot$ Schmidt hammer

(c) University of Warsaw - Faculty of Geography and Regional Studies
Jan Czempiński', Maciej Dąbski²

'Faculty of Geography and Regional Studies, University of Warsaw, Poland

e-mail: jancz9@wp.pl;

${ }^{2}$ Faculty of Geography and Regional Studies, University of Warsaw, Poland e-mail:mfdbski@uw.edu.pl

Received: 26 April 2017 Accepted: 9 August 2017
Introduction

In August 2015, the Austrian Space Forum (ger. Österreichisches Weltraum Forum) conducted the AMADEE15 Mars Mission Simulation in the upper part of the Kaunertal valley in the Ötztal Alps in Tirol (Fig. 1). The aim of the project was to "investigate the limitations and opportunities of studying a Martian (rock) glacier with human explorers, using state-of-theart instrumentation" (Groemer 2015; Groemer et al. 2016). This project was one of a series of similar simulations, but the Kaunertal site had the highest altitude so far: 2600-2887 m a.s.I. During the simulation, analogue astronauts, wearing full space suits, performed experiments in different fields of environmental and human sciences on the Kaunertal glacier, in its foreland and on a nearby rock glacier. One of the experiments was to collect data on the relative age of glacier landforms using lichenometrical measurements (LM) and Schmidt hammer rock tests (SHRT). All experiments were designed by primary investigators ( $\mathrm{PI}$ ) from different European institutions and were supported and controlled by the staff in the Base Habitat at the margin of the Kaunertal glacier and the Mission Support Centre (MSC) in Innsbruck (Groemer et al. 2016).

Apart from the importance of simulating Mars missions and the capabilities of astronauts (Groemer et al. 2016), there is an important environmental issue which justifies our research. The contemporary shrinkage of the cryosphere is resulting in the recession of glaciers and the melting of permafrost on a global scale (Huber et al. 2005), but has also led to a collaborative international effort to gather information on the contemporary behaviour of glaciers and rock glaciers (WGMS 2016; GAPHAZ 2017). This is accompanied by developments and discussions on dating

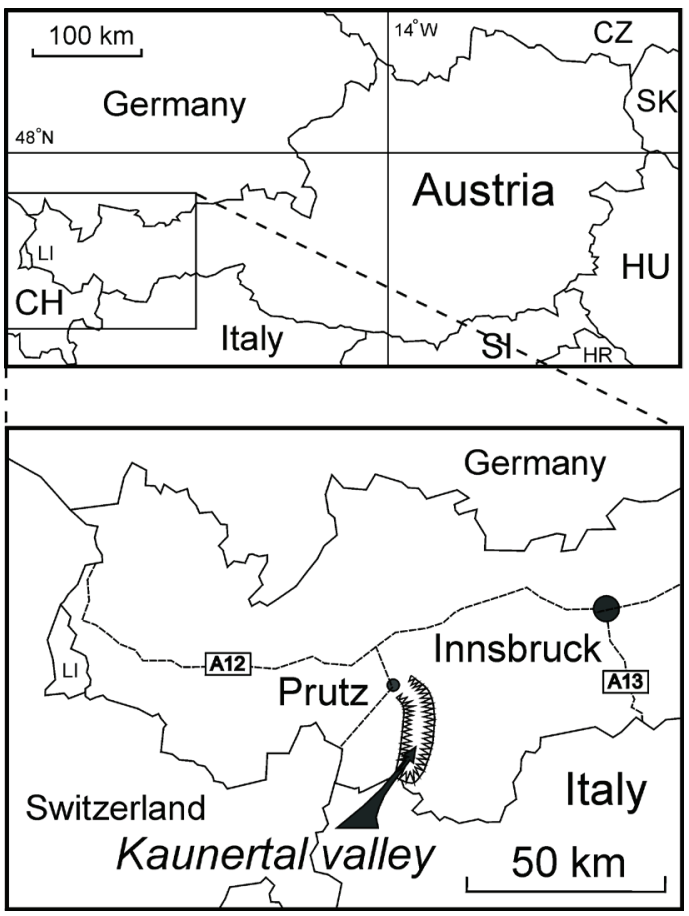

Figure 1. Location of the study site. Source: based on Google Maps 
techniques for glacial landforms (Hubbard \& Glasser 2005), among which lichenometry and Schmidt hammer are very popular, but there are still different approaches to these methods (Winkler \& Shakesby 1995; Evans et al. 1999; Bradwell 2009; Dąbski 2007, 2009, 2014), which justifies our research in Kaunertal.

Holocene fluctuations of glaciers in the Alps have been thoroughly studied by Grove (1990), Zasadni (2007) and Ivy-Ochs et al. (2009), with some studies focusing on the Tyrolean Alps and post Little Ice Age (LIA) recession (Grove 1990, Nicolussi 1990; Winkler \&, Shakesby 1995; Sass 2010). The development of glacial landforms in the Alps has frequently been associated with permafrost thaw (Gruber et al. 2004), the development of taluses and rockwall retreat (Sass 2005; Sanders \& Ostermann 2011; Heckmann et al. 2016), initial soil formation (Temme et al. 2016), and rock glacier activity (Krainer \& Mostler 2006; Krainer \& Ribis 2012).

The aim of this article is to show the results and limitations of the lichenometrical measurements and Schmidt hammer rock tests performed during the AMADEE-15 simulation and to reconstruct the dynamics of Kaunertal glacier recession since the LIA and the timing of Kaunertal rock glacier stabilization.

\section{Study site}

Kaunertal glacier (also known as Weißseeferner) flows north of Weißseespitze (3518 m a.s.I.) in the Ötztal Alps, Austrian Tirol. The snout of the glacier in $2015 \mathrm{AD}$ was at $2680 \mathrm{~m}$ a.s.I. and the LIA terminal moraine ridge at about $2400 \mathrm{~m}$ a.s.l. (altitude of the valley floor), about $1400 \mathrm{~m}$ away from the glacier (Fig. 2).

The local thrust sheets (Ötztal - Bundschuh Nappe System) consist mainly of gneisses, metamorphic schists and amphibolites and was created in Hercynian and early Alpine orogenies (McCann 2008; Pfiffner 2010). The Kaunertal valley was developed mainly from paragneisses and orthogneisses (Tollmann 1977), which poses challenges for SHRT due to the diversity of coarse grained rocks, because large crystals of different minerals vary in strength, resulting in a differential rebound of the impact plunger (R-values). On the other hand, basic or light acidic $\mathrm{pH}$ allows the growth of Rhizocarpon lichens (Poelt 1988) which are best suited for lichenometry due to their slow growth rate (Bradwell \& Armstrong 2006).

The mean annual precipitation (MAP) in the study area is in the range of $1100-1300 \mathrm{~mm}$. Both the MAP and the mean annual air temperature (MAAT) vary between the contemporary glacier margin and the outermost LIA moraine, which is located at an elevation $280 \mathrm{~m}$ lower. It can be estimated that the MAAT in the glacier foreland is between $0^{\circ} \mathrm{C}$ and $-1^{\circ} \mathrm{C}$. Temperature data collected in Vent, located about $10 \mathrm{~km} \mathrm{~W}$ of the study site at 1906 $\mathrm{m}$ a.s.I., indicates a MAAT increase of about $1{ }^{\circ} \mathrm{C}$ in the period 1935-2010 (Institute of Meteorology and Geophysics 2013).

Despite climatic warming, permafrost is still probable near the glacier margin and in the upper parts of the nearby rock glacier (Fig. 2), while in the lower parts of the glacier foreland it can exist only in very favourable conditions (Alpine Permafrost Index Map; Boeckli et al. 2012). Moreover, the topoclimate facilitates frequent ground freezing and thawing, which should lead to quick rock surface weathering after the withdrawal of the glacier. Therefore, we assumed that SHRT R-values would be good weathering indicators of glacial landforms to support the lichenometrical data (Dąski 2014).

\section{Methods}

In order to collect information on the age of glacial landforms and the degree of weathering of deglaciated rock surfaces, fifteen test polygons were located in the foreland of Kaunertal glacier (Table 1, Fig. 3) for LM and SHRT. The measurements were restricted to exposed glacially-abraded rock surfaces, including bedrock (whale backs) and boulders on moraine ridge crests or

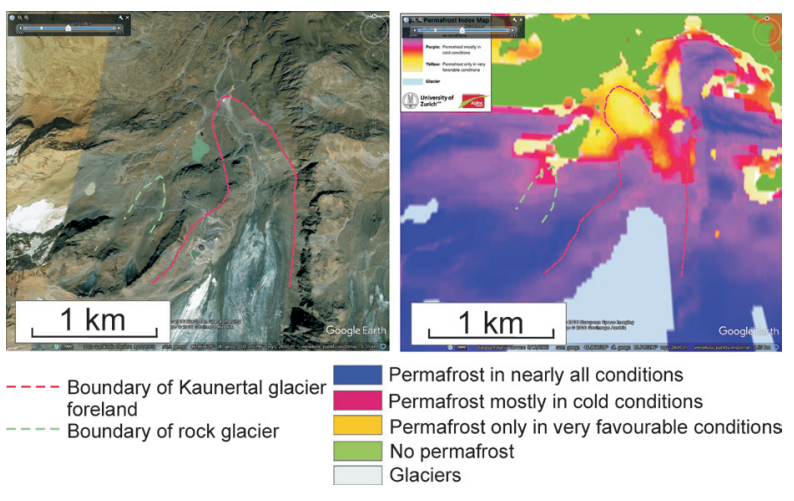

Figure 2. Ground temperature conditions at the study site (based on Google Earth and Alpine Permafrost Index Map).

the upper parts of slopes, or on ground moraine next to the glacier snout. We avoided footslopes, which provide surplus humidity for enhanced lichen growth - so-called "green zones" (Haines-Young 1983). Additionally, one polygon was designed on the nearby rock glacier in its frontal part in order to gather supplementary information about the contemporary dynamics of permafrostrelated landforms (Fig. 3). The polygons were numbered following the expected order of the age of the rock surfaces: from the oldest and furthest from the LIA glacial maximum (polygon number 1 ), to the youngest and most proximal to the glacier (polygon 15). The size of the polygons depended on the sitespecific conditions (covering a piece of a single landform, e.g. moraine ridge or whale back) and varied between 10 and $100 \mathrm{~m}^{2}$.

Based on information about glacial landform development and chronology in the Ötztal Alps (Nicolussi 1990; Winkler \&, Shakesby 1995; Sass 2010), we interpreted the most distant latero-frontal moraine ridge as a landform marking the glacier maximum position in the LIA, created around 1850 AD. Fully-suited analogue astronauts (Fig. 4) performed measurements on polygons 4 and 12, and unsuited astronauts, equipped only with special gloves, on polygons 5,9 and 13 (Table 1 ).

The number of measured lichen thalli and Schmidt hammer (SH) blows depended on the availability of suitable rock surfaces and lichens - for example, on the young surface of polygon 13 (near the glacier) only 5 thalli were measured, because there were no more available, but in polygon 5 (LIA maximum) there were 221 thalli measured. The number of $\mathrm{SH}$ blows usually varied between 90 and 100, with an exception for polygon 4 where the fully-suited astronaut performed only 32 blows (Table 1). SHRT were restricted to glacially abraded rock surfaces, whether they were made up of bedrock or large boulders. Moreover, the rock surfaces had to be free of any visible fissures which weaken the rock strength. Ideally, ten representative places were selected in each polygon and ten blows were performed in each place, keeping a minimum $1 \mathrm{~cm}$ distance between the blow points and 6 $\mathrm{cm}$ distance from any visible rock surface irregularities according to the recommendations of Day and Goudie (1977). The mobility of the suited astronauts was very low, partly due to safety reasons, so the number of measured lichen thalli had to be limited. Moreover, the suited astronauts had very little experience with LM and SHRT, so the data collection proceeded slowly. A graduate student of geomorphology supplemented the study by collecting data from the rest of the polygons.

The measured lichens belonged to the yellow-green Rhizocarpon subgenus (Fig. 5) (Benedict 1988), and only the enveloping circles of relatively circular thalli were measured (1 $\mathrm{mm}$ precision) with the use of a ruler (Dabski 2007; Sass 2010). 


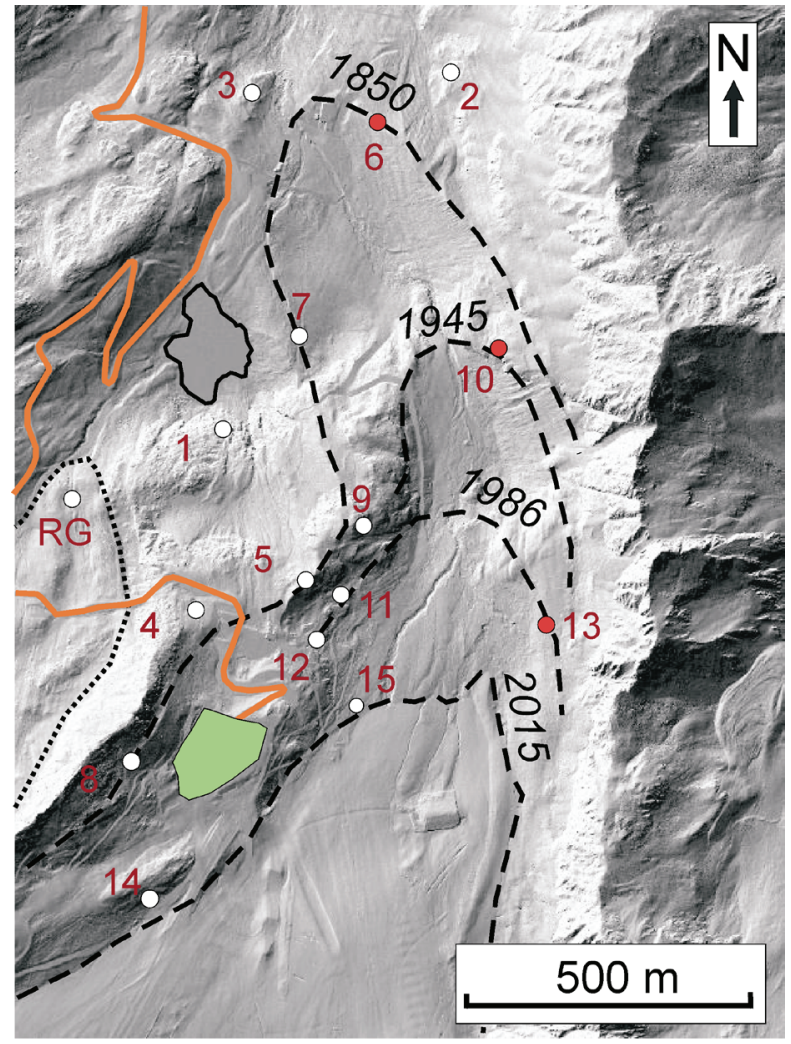

$7^{\circ}$ test polygon with its numebr

$10^{\circ}$ benchmark polygon

- - - glacial terminus in given year (AD)

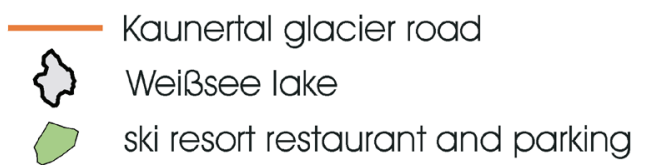

Figure 3. Location of test polygons and subsequent positions of Kaunertal glacier margin (based on WGMS 2016 and tirisMaps 2.0 2016).

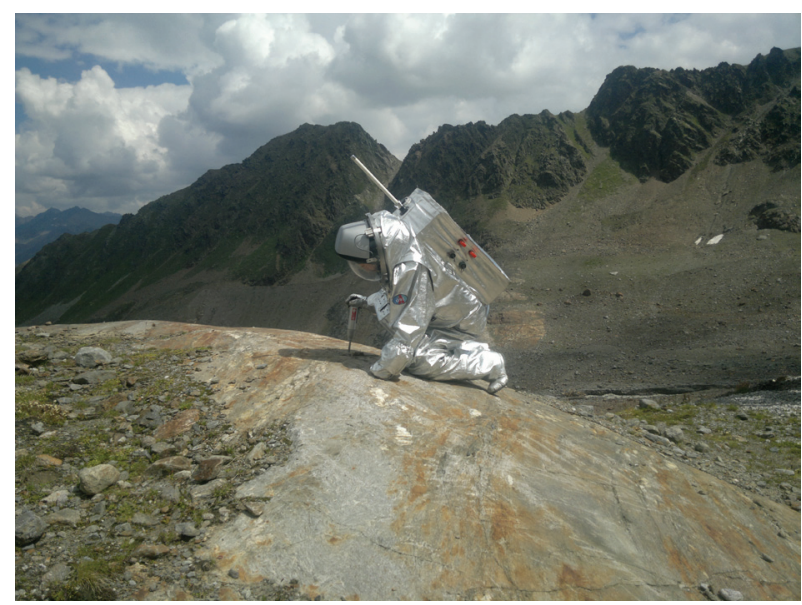

Figure 4. Fully-suited analogue astronauttaking SHRT measurements on glacially abraded bedrock (polygon no. 12).

Source: Taken by the M. Dąbski.

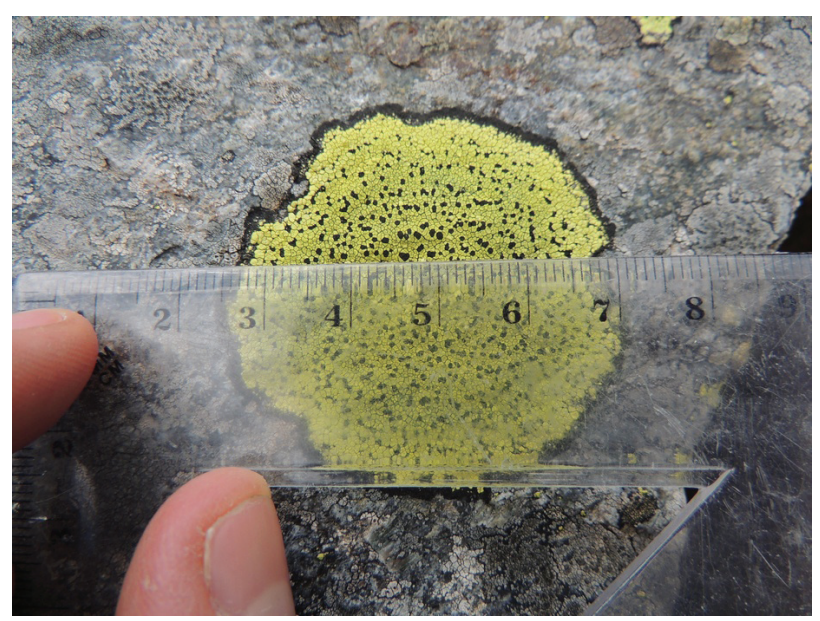

Figure 5. A thalli of Rhizocarpon lichen suitable for dating. Source: Taken by the M. Dąbski.

The dates of the onset of subaerial weathering of two polygons (numbers 10 and 13) were known, based on data on the Kaunertal glacier recession history recorded in the World Glacier Monitoring Service (WGMS) database, and the age of polygon 6 (outermost frontal moraine) was inferred after Nicolussi (1990), Winkler and Shakesby (1995) and Sass (2010). These three polygons were taken as benchmarks (Fig. 3) for the construction of the lichen growth curve. Using the popular technique of the five largest thalli (5LL) (Bradwell 2009) we obtained an equation:

$y=14.36 \ln (x)-37.3 \quad\left(R^{2}=0.96\right)$

where $y$ is lichen diameter and $x$ is age of rock surface (age of landforms). The logarithmic line was chosen (Fig. 6) because it mirrors the time-dependant decrease in lichen growth rate (Winkler \& Shakesby 1995; Sass 2010; Dąbski 2014; Armstrong 2016).

For a comparison, we present the lichen growth rates developed by Winkler and Shakesby (1995) who worked in Rofental, a valley immediately east of Kaunertal (Fig. 6, dotted line), and by Sass (2010) who worked in Finstertal, located $40 \mathrm{~km}$ NE of Kaunertal (Fig. 6, dashed line). We additionally calculated the dates of the studied landforms using the equation developed by Winkler and Shakesby (1995) for 5LL and for LL (single largest thallus), assuming that the natural environment of Rofental is very similar to that of Kaunertal (Table 1).

We decided to verify the robustness of our LM and SHRT as dating techniques of the glacier foreland by correlating them with the data derived from the glacier recession history (WGMS 2016) and literature concerning other glaciers in the Ötztal Alps (Nicolussi 1990; Winkler \& Shakesby 1995; Sass 2010). Due to the lack of LM for polygons 1, 2, 14 and 15, and the lack of SHRT results for polygons 6, 7 and 11, we decided to use a Spearman rank correlation (Fig. 7). We derived the expected dates from the distance between the test polygons and the known positions of the glacier margin (based on WGMS 2016) and the development of glacier landforms.

\section{Results}

Our results show that the most prominent lateral-frontal moraine ridge of Kaunertal glacier, which we associate with the LIA glacial maximum based on Nicolussi (1990), Winkler and Shakesby (1995) and Sass (2010), was probably formed in several stages: in 1676 AD (polygon 7), 1834 AD (polygon 6), 1881 AD (polygon 8) and finally in $1915 \mathrm{AD}$ (polygon 5), and the stabilization of the 


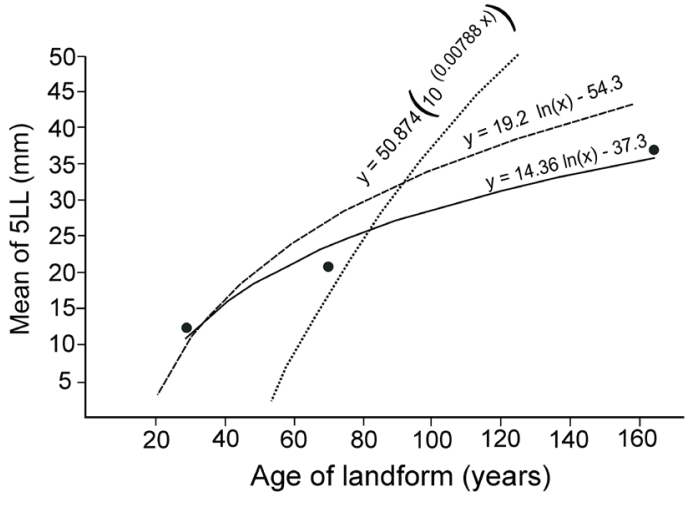

Figure 6. Solid line: Rhizocarpon growth curve used in this study, based on sites of known age (polygons 6, 10, 13); dotted line: lichen growth curve obtained by Winkler and Shakesby (1995) in Rofental (5LL approach); dashed line: lichen growth curve obtained by Sass (2010) in Finstertal. frontal part of the nearby rock glacier occurred in $1711 \mathrm{AD}$ (Table 1, Fig. 6). A subsequent recession of the glacier, followed by a minor transgression and a stillstand in the first two decades of the $20^{\text {th }}$ century (WGMS 2016), did not leave any geomorphic imprint in the glacier foreland. The next minor transgression and stillstand of the glacier between 1970 and 1986 AD created a small but discernible lateral moraine ridge (Fig. 3).

We found significant discrepancies between the expected dates and the lichenometrically obtained dates (Table 1).

Despite the differences in the dates obtained, the Spearman rank correlation is a strong positive one (Fig. 7, diagram A). If test polygon 4 was disregarded, taking into consideration the very limited amount of lichen thalli measured by the fullysuited analogue astronauts (Table 1), the correlation would be stronger.

The growth rates (LL and 5LL approaches) developed by Winkler and Shakesby (1995) in Rofental seem to work reasonably well in Kaunertal but only for landforms associated with the LIA and the onset of the $20^{\text {th }}$ century. However, they produced clearly unacceptable dates for the landforms developed since 1945 AD (Table 1, Fig. 3).

Table 1. Results of measurements.

\begin{tabular}{|c|c|c|c|c|c|c|c|c|c|}
\hline $\begin{array}{l}\text { Polygon } \\
\text { number }\end{array}$ & $\mathrm{PR}^{*}$ & $\begin{array}{l}\text { No. of } \\
\text { measured } \\
\text { thalli }\end{array}$ & $\begin{array}{l}5 \text { largest } \\
\text { thalli }\end{array}$ & $\begin{array}{c}5 \mathrm{LL} \\
\text { (mean) }\end{array}$ & $\begin{array}{l}\text { Expected } \\
\text { date } \\
(A D)^{* *}\end{array}$ & $\begin{array}{l}\text { Obtained date } \\
\text { according to our } \\
\text { growth rate }\end{array}$ & $\begin{array}{l}\text { Obtained date } \\
\text { according to } \\
\text { growth rate of Winkler } \\
\text { \& Shakesby }(1995)^{\star * *}\end{array}$ & $\begin{array}{c}\text { Number } \\
\text { of SHRT } \\
\text { blows }\end{array}$ & $\begin{array}{l}\text { Mean } \\
\text { R-value with } \\
\text { standard } \\
\text { error }\end{array}$ \\
\hline 1 & $\mathrm{G}$ & 0 & - & - & $<$ LIA & - & - & 97 & $41.4 \pm 0.69$ \\
\hline 2 & G & 0 & - & - & $<$ LIA & - & - & 100 & $27.7 \pm 0.64$ \\
\hline 3 & G & 81 & $\begin{array}{c}65,57,52 \\
50,50\end{array}$ & 54.8 & $<$ LIA & 1406 & $1851 / 58$ & 98 & $47.1 \pm 0.67$ \\
\hline 4 & SA & 26 & $\begin{array}{c}35,28,24 \\
23,23\end{array}$ & 26.6 & $<$ LIA & 1929 & $1908 / 12$ & 32 & $40.7 \pm 1.33$ \\
\hline 5 & UA & 221 & $\begin{array}{c}32,29,28 \\
28,27\end{array}$ & 28.8 & $\begin{array}{l}\text { LIA max. } \\
\text { (1850?) }\end{array}$ & 1915 & $1908 / 12$ & 100 & $52.1 \pm 0.71$ \\
\hline 6 & G & 90 & $\begin{array}{c}38,38,38 \\
37,36 \\
\end{array}$ & 37.4 & $\begin{array}{l}\text { LIA max. } \\
\text { (1850 ?) }\end{array}$ & 1834 & $1894 / 1904$ & 0 & - \\
\hline 7 & G & 49 & $\begin{array}{c}56,45,45 \\
44,42\end{array}$ & 46.4 & $\begin{array}{l}\text { LIA max. } \\
\text { (1850 ?) }\end{array}$ & 1676 & $1871 / 77$ & 0 & - \\
\hline 8 & G & 43 & $\begin{array}{c}42,35,31 \\
30,27\end{array}$ & 33.0 & $\begin{array}{l}\text { LIA max. } \\
\text { (1850 ?) }\end{array}$ & 1881 & $1897 / 1901$ & 100 & $55.1 \pm 0.44$ \\
\hline 9 & UA & 137 & $\begin{array}{c}25,20,20 \\
19,19\end{array}$ & 20.6 & 1900 & 1959 & $1920 / 21$ & 90 & $54.9 \pm 0.7$ \\
\hline 10 & G & 53 & $\begin{array}{c}23,22,20 \\
20,19\end{array}$ & 20.8 & 1945 & 1958 & $1919 / 23$ & 100 & $62.0 \pm 0.31$ \\
\hline 11 & G & 70 & $\begin{array}{c}21,19,17 \\
17,14 \\
\end{array}$ & 17.6 & 1970 & 1969 & $1924 / 26$ & 0 & - \\
\hline 12 & SA & 7 & $9,8,7,7,6$ & 7.4 & 1986 & 1993 & $1935 / 38$ & 100 & $42.9 \pm 0.78$ \\
\hline 13 & UA & 5 & $\begin{array}{c}16,15,12 \\
10,9 \\
\end{array}$ & 12.4 & 1986 & 1983 & $1930 / 31$ & 100 & $55.1 \pm 0.43$ \\
\hline 14 & G & 0 & - & - & 2010 & - & - & 100 & $49.8 \pm 0.4$ \\
\hline 15 & $G$ & 0 & - & - & 2010 & - & - & 100 & $53.6 \pm 0.73$ \\
\hline RG & G & 49 & $\begin{array}{c}48,47,45 \\
43,41\end{array}$ & 44.8 & LIA & 1711 & $1879 / 89$ & 0 & - \\
\hline
\end{tabular}

${ }^{*} P R$ - performer (G - trained student of geomorphology, SA - fully-suited analogue astronaut, UA - unsuited analogue astronaut); ${ }^{* *}$ Expected dates are based on the distance between the test polygons and known positions of glacier margin based on WGMS 2016 data and development of glacier landforms; ${ }^{* * *}$ differences in dates result from $L L$ and $5 L L$ approaches. 

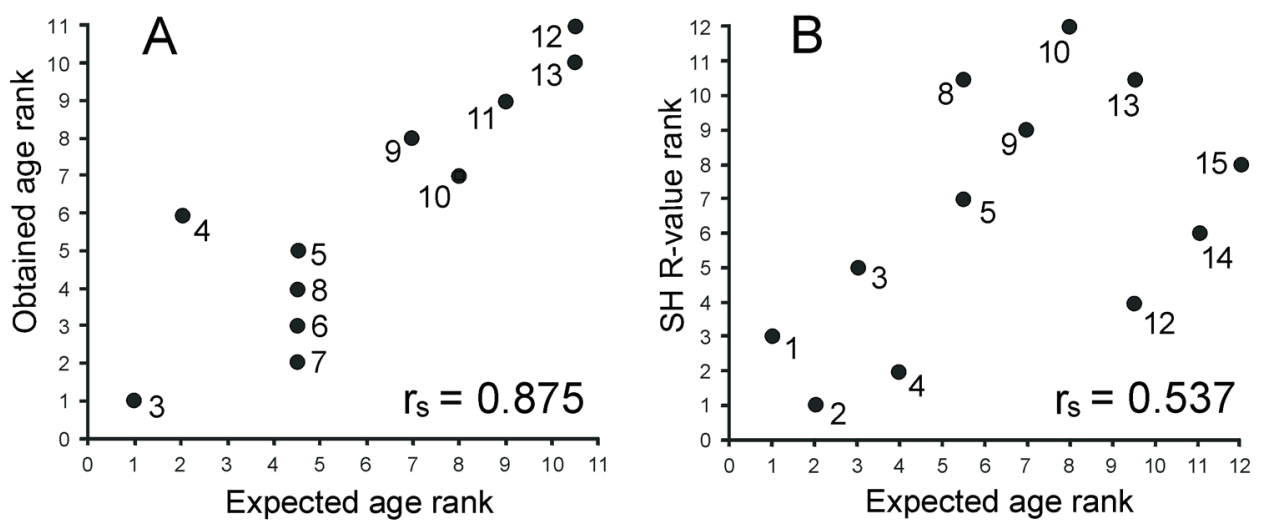

Figure 7. Spearman rank correlations: $A$ - between expected age rank and lichenometrically derived age rank (ranking is from oldest to youngest landforms); $B$ - between expected age rank and Schmidt hammer R-value rank (from weakest $R$-values: most weathered rock, to strongest: least weathered); each dot has a polygon number. Both correlations are statistically significant.

There is only a moderate correlation between the SHRT results and the proper sequence of landform age (Fig. 7, diagram B), which results mainly from the unexpectedly low R-values in polygons 12 and 14, one of which was measured by the fullysuited analogue astronauts (Table 1).

\section{Discussion}

Despite the limited mobility of the analogue astronauts during the AMADEE-15 mission in Kaunertal, the lichenometric and Schmidt hammer experiments proved that both can be performed under simulated Martian conditions. So far, no lichen thalli have been found growing on Mars, but the experiments of Brandt et al. (2015) showed that Xanthoria elegans, a lichen species once used in lichenometry (Beschel 1954), can survive the harsh Martian conditions. It is therefore not unimaginable that lichenometry will one day be employed on the Red Planet. The use of Schmidt hammers on real Martian missions is much more probable, and the only factor which needs to be taken into account would be the Martian surface acceleration, which is almost three times lower than on Earth (Mars Fact Sheet). The instrument is calibrated for operation in a horizontal position, which allows vertical rock surfaces to be tested. If the position of $\mathrm{SH}$ is oblique or horizontal, then the gravity component which acts on the striking weight needs to be considered (Runkiewicz \& Brunarski 1977), but this is a matter of a simple calculation.

The limited number of test polygons and measured lichen thalli, and the inconsistent number of $\mathrm{SH}$ blows per polygon precludes a far-reaching interpretation; however, several issues can be stated. The performance of LM and SHRT by different people with different mobility and experience levels (fullysuited astronauts, unsuited astronauts, and a trained student of geomorphology) resulted in a data set which cannot be fully trusted in the reconstruction of the area's geomorphic history. The procedures employed in the AMADEE-15 simulation required that the fully-suited astronauts working in the field had no direct contact with the primary investigator of the experiment. The only communication the astronauts had was with the MCS in Innsbruck, where flight control staff had precise information on the position and activity of the astronauts thanks to GPS and radio transmissions (Groemer 2015; Groemer et al. 2016). Therefore, errors resulting from the improper selection of lichen thalli or handling of SH could not be corrected in the field. The technical limitations to the astronauts' mobility additionally hindered proper data collection. The significant differences between the majority of obtained dates and the expected dates are disappointing, despite the strong rank order correlation, and prove that the results of lichenometric dating should be approached with caution if not obtained by an experienced measurer.

The obtained results can also be explained by the fact that the studied rock surfaces were coarse-grained metamorphic rocks (paragneisses and orthogneisses), which are not wellsuited to SHRT. The lamellar structure and large size of the different minerals can significantly modify the R-values. The SH operator directs the impact plunger to minerals of differential strength and distance from discontinuities, which are sometimes not easily visible. Therefore, the internal structure and texture of paragneisses and orthogneisses can significantly influence SHRT results and offset the influence of weathering duration (Goudie 2006). Another factor is the varying number of measured thalli in different polygons (from 5 to 221). This was determined by the limited size of dated rock surfaces and the diversified availability of suitable lichen thalli.

Moreover, in our calculation of lichen growth rate we did not take into account the difference in altitude between the lowermost test polygons $(3,6,8)$ located near the LIA frontal moraine at about $2400 \mathrm{~m}$ a.s.l. and the highest polygon (8) located above the glacier at an altitude of around $2800 \mathrm{~m}$ a.s.l. This is a significant denivelation, resulting in different climatic conditions, which may have influenced the Rhizocarpon growth rate (Kędzia 2015). Our growth rate decreases together with the increasing age of the lichen and the decreasing altitude. However, as the altitude decreases, the topoclimatic conditions improve, which probably facilitates lichen growth. We assume that this phenomenon is somehow offset by the general negative tendency of lichen growth rate together with increasing age (Dabski 2014).

In the case of polygon 7, located on the LIA lateral moraine ridge (Fig. 3), the obtained date $1676 \mathrm{AD}$ (Tab. 1) is much older than the other dates for this landform sampled in polygons 5, 6 and 8. The vicinity of Lake Weißsee (Fig. 3) could have influenced the topoclimatic conditions at polygon 7 by increasing air humidity, resulting in the faster growth of the lichens (Armstrong 2006). It is also possible that the largest measured thalli in this polygon are the remnants of the lichen population established soon after the glacier transgression in the $17^{\text {th }}$ century. According to Grove (1990) and Winkler and Hagedorn (1995, after Winkler \& Shakesby 1995), between $1678 \mathrm{AD}$ and $1681 \mathrm{AD}$ there was an advance of the nearby Vernagtferner glacier close to its LIA maximum, and it is possible that the Kaunertal glacier behaved in a similar way. The 
much younger-than-expected age (1915 AD) for polygon 5 (Fig. 3 , Table 1) can be explained by a possible advance or stillstand of the glacier, as was shown for Vernagtferner and Rofenkarferner (Winkler \& Shakesby 1995), followed by the start of a general retreat. However, the morphology of the LIA lateral-frontal moraine ridge is quite simple and does not provide an additional argument to support the hypothesis of a multi-stage development.

Winkler and Shakesby (1995) developed their lichenometric growth rates for Rofental excluding any benchmarks younger then c. 50 years, apparently due to the lack of available thalli. This probably explains the too-old dates for polygons $10,11,12$ and 13 , which have deglaciated since 1945 AD. Moreover, the growth rates of Winkler and Shakesby (1995) produced too-young dates (>1850 $A D)$ for polygons 3 and 4 , located outside the LIA maximum, which is at odds with the general knowledge of the area. On the other hand, the dates for polygons 7 and 10, related to the LIA and the onset of the $20^{\text {th }}$ century, are more reasonable than the dates obtained with our growth curve (Table 1). It is always better to calculate the lichen growth rate using local benchmarks, so it is reasonable to place more trust in our growth curve and look for explanations of the unexpected results via data collection and environmental site-specific conditions.

Our LM dating suggests that the rock glacier has been relatively stable in its frontal part since $1711 A D$, which corresponds well with the general knowledge of the LIA timing (Zasadni 2007). However, the Alpine Permafrost Index Map shows that permafrost should still be present in the central and upper parts of the rock glacier, allowing for some movement of the landform. Bearing in mind that large Rhizocarpon geographicum thalli (exceeding $40 \mathrm{~mm}$ ) can be found on the surfaces of active rock glaciers in the Alps (Burga et al. 2004), we conclude that lichenometry cannot be used as a simple method for dating the stabilization of these landforms.

There was an expectation of an increase in rock strength (R-values) in the direction from the oldest to the youngest polygons within the glacier foreland. This supports the previous finding of Dąbski (2009), who worked on post-LIA glacially abraded limestones in the Swiss Alps, as well as Dapski $(2014,2015)$, Evans et al. (1999), and Dabski and Tittenbrun (2013), who worked on freshly deglaciated basalts in Iceland. They showed that SHRT R-values decrease by 5 to $9 \%$ in a direction from the youngest to oldest moraines marking the LIA maxima of glaciers. None of these studies showed strong correlations between the duration of rock surface weathering and R-values, but the tendencies were always noticeable. On the other hand, Matthews and Owen (2008), who carried out SHRT on gneiss in the Storbreen foreland in Norway, found no significant trend in R-values on lichen-free rocks, but the rock surfaces covered by endolithic lichen Lecidea auriculata exhibited a swift decrease in strength by $44 \%$, which occurred in the first four decades following liberation from glacial ice.

\section{Conclusions}

The lichenometric and Schmidt hammer experiments during the AMADEE-15 Mars Mission Simulation proved that both can be performed under simulated Martian conditions. The LM and SHRS experiments in Kaunertal did not yield trustworthy information on the age of studied landforms due to several reasons, including the differences in field experience of the people performing the measurements and the limited mobility of the analogue astronauts. Nevertheless, the experiments proved that these methods are within the range of the astronauts' capabilities.

The lichenometrically-derived dates for the Kaunertal glacier foreland differ significantly from the expected dates, but the rank correlation is strong. The environmental factors responsible for the results obtained are: i) variations in the petrography of the tested rocks, ii) differences in the number of available thalli in test polygons, and iii) changing climatic conditions. There is also a possible error in the construction of our lichenometric growth curve, due to the climatic differences between the lowermost and uppermost parts of the glacier foreland.

Despite the mentioned limitations, we were able to state the probable multi-stage development of the LIA lateral-frontal moraine of the Kaunertal glacier (from the second half of the $17^{\text {th }}$ century to the beginning of the $20^{\text {th }}$ century). Lichens growing on the frontal part of the rock glacier suggest a relative stabilization of the substrate since $1711 \mathrm{AD}$, but this does not preclude the continuous activity of the landform. The moderate correlation between the decreasing age of the glacial landforms and the increasing Schmidt hammer R-values is in accordance with findings from glacier forelands in other parts of the world.

\section{Acknowledgements}

We would like to thank Anna Łosiak and Gernot Groemer for the invitation to the AMADEE-15 Mars Mission Simulation. One of the employees of the Faculty of Geography and Regional Studies, University of Warsaw, was the PI of LM and SHRT. A graduate student from the same faculty performed supplementary measurements and based his M.Sc. thesis on this project. The article benefitted significantly from the constructive comments of the reviewers.

\section{References}

Alpine Permafrost Index Map (APIM) 2016. Available from: <http:// www.geo.uzh.ch/microsite/cryodata/PF_map_explanation. html>. [16 December 2016].

Armstrong, RA 2006, 'Seasonal growth of the crustose lichen Rhizocarpon geographicum (L.) DC. in South Gwynedd, Wales', Symbiosis, vol. 41, no. 2, pp. 97-102.

Armstrong, RA 2016, 'Lichenometric dating (lichenometry) and the biology of the lichen genus Rhizocarpon: challenges and future directions', Geografiska Annaler, vol. 98(A), no. 3, pp. 183-206. DOI: 10.1111/geoa.12130.

Benedict, JB 1988, 'Techniques in lichenometry: identifying the yellow Rhizocarpons', Arctic and Alpine Research, vol. 20, pp. 285-291.

Beschel, RE 1954, 'Eine Flechte als Niederschlagsmesser', Wetter and Leven, vol. 6-7, pp. 56-60.

Boeckli, L, Brenning, A, Gruber, S \& Noetzli, J 2012, 'Permafrost distribution in the European Alps: calculation and evaluation of an index map and summary statistics', The Cryosphere, vol. 6, pp. 807-820. DOI: 10.5194/tc-6-807-2012.

Bradwell, T 2009, 'Lichenometric dating: a commentary, in the light of some recent statistical studies', Geografiska Annaler, vol. 91(A), no. 2, pp. 61-69. DOI: 10.1111/j.1468-0459.2009.00354.x.

Bradwell, T \& Armstrong, RA 2006, 'Growth rates of Rhizocarpon geographicum lichens: a review with new data from Iceland', Journal of Quaternary Science, vol. 22, no. 4, pp. 311-320._DOI: 10.1002/jqs.1058.

Brandt, A, de Vera, JP, Onofri, S \& Ott, S 2015, 'Viability of the lichen Xanthoria elegans and its symbionts after 18 months of space exposure and simulated Mars conditions on the ISS', International Journal of Astrobiology, vol 14, no. 3, pp. 411-425. DOI: https://doi.org/10.1017/ S1473550414000214.

Burga, CA, Frauenfelder, R, Ruffet, J, Hoelzle, M \& Kääb, A 2004, 'Vegetation on Alpine rock glacier surfaces: a contribution to 
abundance and dynamics on extreme plant habitats', Flora, vol. 199, pp. 505-515.

Day, MJ \& Goudie, AS 1977, 'Field assessment of rock hardness using the Schmidt test hammer', British Geomorphological Research Group Technical Bulletin, vol. 18, pp. 19-29.

Dabski, M 2007, 'Testing the size-frequency-based lichenometric dating curve on Fláajökull moraines (SE Iceland) and quantifying lichen population dynamics with respect to stone surface aspect', Jökull, vol. 57, pp. 21-35.

Dąbski, M 2009, 'Early stages of weathering of glacially-abraded limestone surfaces as determined by various Schmidt hammer tests; Biferten glacier forefield, Glarner Alps (Switzerland)', Landform Analysis, vol. 11, pp. 13-18.

Dąbski, M 2014, 'Rock surface micro-roughness, Schmidt hammer rebound and weathering rind thickness within LIA Skálafellsjökull foreland, SE Iceland', Polish Polar Research, vol. 35, no. 1, pp. 99-114. DOI: 10.2478/popore-2014-0008.

Dąbski, M 2015, 'Application of the Handysurf E-35B electronic profilometer for the study of weathering micro-relief in glacier forelands in SE Iceland', Acta Geologica Polonica, vol. 65, no. 3, pp. 389-401. DOI: 10.1515/agp-2015-0018.

Dąbski, M \& Tittenbrun, A 2013, 'Time-dependant surface deterioration of glacially abraded basaltic boulders deposited by Fláajökull, SE Iceland', Jökull, vol. 63, pp. 55-70.

Evans, DJA, Archer, S \& Wilson, DJH 1999, 'A comparison of the lichenometric and Schmidt hammer dating techniques based on data from the proglacial areas of some Icelandic glaciers', Quaternary Science Reviews, vol. 18, pp. 13-41. DOI: 10.1016/S0277-3791(98)00098-5.

Glacier and Permafrost Hazards in Mountains (GAPHAZ) 2017. Available from: <www.gaphaz.org>. [20 June 2017].

Goudie, AS 2006, 'The Schmidt Hammer in geomorphological research', Progress in Physical Geography, vol. 30, no. 6, pp. 703-718. DOI: 10.1177/0309133306071954.

Groemer, G 2015, AMADEE-15 Mission Report, Available from: <http://oewf.org/wp-content/uploads/downloads/2015/09/ AMADEE-15_FinalReport_PUBLIC_V3.pdf>. [12 December 2016].

Groemer, G, Losiak, A, Soucek, A, Plank, C, Zanardinia, L, Sejkora, N \& Sams, S 2016, 'The AMADEE-15 Mars simulation', Acta Astronautica, vol. 129, pp. 277-290. DOI: https://doi.org/10.1016/j.actaastro.2016.09.022.

Grove, JM 1990, Little Ice Ages, Routledge, London. Gruber, S, Hoelzle, M \& Haeberli, W 2004, 'Permafrost thaw and destabilization of Alpine rock walls in the hot summer of 2003', Geophysical Research Letters, vol. 31, L13504. DOI: 10.1029/2004GL020051.

Haines-Young, RH 1983, 'Size variation of Rhizocarpon on Moraine Slopes in Southern Norway', Arctic and Alpine Research, vol 15, no 3, pp. 295-305.

Heckmann, A, Hilger, L, Vehling, L \& Becht, M 2016, 'Integrating field measurements, a geomorphological map and stochastic modelling to estimate the spatially distributed rockfall sediment budget of the Upper Kaunertal, Austrian Central Alps', Geomorphology, vol. 260, pp. 16-31. DOI: https://doi. org/10.1016/j.geomorph.2015.07.003.

Hubbard, B \& Glasser, N 2005, Field Techniques in Glaciology and Glacial Geomorphology. John Wiley \& Sons, Chichester.

Huber, VM, Bugmann, HKM \& Reasoner, MA (eds.) 2005, Global Change and Mountain Regions. An Overview of Current Knowledge. Springer, Dordrecht.

Institute of Meteorology and Geophysics 2013, Climate Data Vent, Ötztal Alps, 1935-2011, University of Innsbruck. DOI: 10.1594/PANGAEA.806582.

Ivy-Ochs, S, Kerschner, H, Maisch, M, Christl, M, Kubik, PW \& Schluchter, C 2009, 'Latest Pleistocene and Holocene glacier variations in the European Alps', Quaternary Science
Reviews, vol. 28, no. 21-22, pp. 2137-2149. DOI: 10.1016/j. quascirev.2009.03.009.

Kędzia, S 2015, 'Lichenometric curves for the PoliSHRT part of the Karkonosze and Tatra Mountains establiSHRTed with a new method', Zeitschrift fürGeomorphologie, vol. 59, no. 1, pp. 103-118. DOI: 10.1127/0372-8854/2014/0141.

Krainer, K\& Mostler, W 2006, 'Flow velocities of active rock glaciers in the Austrian Alps', Geografiska Annaler, vol. 88(A), no. 4, pp. 267-280. DOI: 10.1111/j.0435-3676.2006.00300.x

Krainer, K \& Ribis, M 2012, 'A rock glacier inventory of Tyrolean Alps (Austria)', Austrian Journal of Earth Sciences, vol. 105, no. 2, pp. 32-47.

Mars Fact Sheet (n.d.), Mars/Earth Comparison 2017. Available from: <https://nssdc.gsfc.nasa.gov/planetary/factsheet/ marsfact.html>. [19 June 2017].

Matthews, JA \& Owen, G 2008, 'Endolithic lichens, rapid biological weathering and Schmidt hammer R-values on recently exposed rock surfaces: Storbreen glacier foreland, Jotunheimen, Norway', Geografiska Annaler, vol. 90(A), no. 4, pp. 287-297. DOI: 10.1111/j.1468-0459.2008.00346.x.

McCann, T 2008, Geology of Central Europe, Geological Society of London, London.

Nicolussi, K 1990, 'Bilddokumente zur Gleschichte des Vernagtfermers im 17. Jahrhundert', Zeitschrift für Gletscherkunde und Glazialgeologie, vol. 26, pp. 97-119.

Pfiffner, OA 2010. Geologie der Alpen. 2nd ed. Geologie of UTB. Haupt, Bern.

Poelt, J 1988, 'Rhizocarpon Ram. em. Th. Fr. Subgen. Rhizocarpon in Europe', Arctic and Alpine Research, vol. 20, no. 3, pp. 292-298

Runkiewicz, L \& Brunarski, L 1977, 'Instrukcja stosowania młodków Schmidta do nieniszczącej kontroli jakości betonu w konstrukcji, nr 210', Instytut techniki Budowlanej, Warszawa.

Sanders, D \& Ostermann, M 2011, 'Post-last glacial alluvial fan and talus slope associations (Northern Calcareous Alps, Austria): A proxy for Late Pleistocene to Holocene climate change', Geomorphology, vol. 131, no. 3-4, pp. 85-97. DOI: 10.1016/j.geomorph.2011.04.029.

Sass, O 2005, 'Temporal variability of rockfall in the Bavarian Alps, Germany', Arctic, Antarctic and Alpine Research, vol. 37, no. 4, pp. 564-573. DOI: 10.1657/1523-0430(2005)037[ 0564:TVORIT]2.0.CO;2.

Sass, O 2010, 'Spatial and temporal patterns of talus activity - a lichenometric approach in the Stubaier Alps, Austria', Geografiska Annaler, vol. 92(A), no. 3, pp. 375-391. DOI: 10.1111/j.1468-0459.2010.00402.x.

Temme, AJ, Heckmann, T, Harlaar, P 2016, 'Silent play in a loud theatre - Dominantly time-dependent soil development in the geomorphically active proglacial area of the Gepatsch glacier, Austria', Catena, vol. 147, 40-50.

TirisMaps 2.0., 2016. Available from: <https://www.tirol.gv.at/ statistik-budget/tiris/>. [20 December 2016].

Tollmann, A 1977, Geologie von Österreich. Die Zentralalpen, vol. 1. Franz Deuticke, Vienna.

Winkler, S, Shakesby, RA 1995, 'Anwendung von Lichenometrie und Schmidt-Hammer zur relativen Altersdatierung präfrührezenter Moränen am Beispiel der Vorfelder von Guslar-, Mitterkar-, Rofenkar- und Vernagtferner (Ötztaler Alpen/ Österreich)', Petermanns Geographische Mitteilungen, vol. 139, pp. 283-304.

WGMS FoG database, version 2016-08-16. Available form: <http://wgms.ch/about wgms/>. [3 March 2016]. DOI: 10.5904/wgms-fog-2016-08.

Zasadni, J 2007, 'The Little Ice Age in the Alps: its record in glacial deposits and rock glacier formation', Studia Geomorphologica Carpatho-Balcanica, vol. 41, 117-137. 